\title{
Reflections from a tarnished mirror: an application of Alvesson and Sköldberg's "reflexive interpretation" to a study of curriculum design in higher education
}

\begin{abstract}
It is now widely understood that reflexivity constitutes a vital element of good qualitative research. However, reflexive accounts often draw on a single theoretical framework, thus privileging and legitimizing a particular interpretation of empirical data. This paper focuses on Alvesson and Sköldberg's "reflexive interpretation," which arises from an interplay between the perspectives of grounded theory, hermeneutics, critical theory and postmodernism. The positioning of the researcher in such a multiparadigmatic relationship to the empirical data offers the potential for deeper meaning. By applying Alvesson and Sköldberg's approach to a case study of curriculum design, I explore issues of teaching reflection to postgraduate students. Problematizing case study data at the level of hermeneutics provides insights into the temporality, complexity and symbolic meaning disclosed through the interpretive act. Whilst critical theory locates the findings within the political-ideological context, the postmodern perspective questions my power and authority as a teacherresearcher of reflection.
\end{abstract}

Keywords: reflexivity, qualitative methodology, reflexive interpretation

Defined as a process of critical self-reflection, reflexivity is crucial for establishing authenticity in qualitative research (Guba and Lincoln 2005) and fundamental to the integrity of the researcher (Boler 2008). Reflexivity involves detachment, self-distancing and self-restraint (Elias 1987), which enable the researcher to recognize his/her epistemological influences. These influences have a bearing on all stages of a research project, from its conception to completion and evaluation (Grace 1998). A 'good' qualitative research study would be incomplete without a reflexive account of the research process. However, as Alvesson and Sköldberg (2009) contend, reflexive accounts often draw on a single theoretical 
framework, thus legitimizing and privileging a particular interpretation of empirical data. Premised on an understanding that research findings are constructions and results of interpretation, Alvesson and Sköldberg's (2009) reflexive methodology includes an analysis and evaluation of empirical data at four levels of interpretation. It involves: problematizing the empirical material, an engagement in the interpretive (hermeneutic) act, clarification of the politicalideological context and consideration of questions of representation and authority. "Reflexive interpretation" aims at enriching the practice of reflexivity through the interplay of these multiple theoretical approaches:

Reflexive interpretation is the opposite of empiricism and theoreticism (the use of a single, abstract framework offering a privileged understanding)... Reflexivity arises when the different elements of levels are played off against each other. It is in these relations and in the interfaces that reflexivity occurs. (Alvesson and Sköldberg 2009, 272)

This paper applies "reflexive interpretation" to a small scale study of postgraduate curriculum design. The research was designed as a case study evaluating teaching and learning of reflection in an MA Education module. Following Alvesson and Sköldberg's (2009) framework, empirical data were analyzed from the perspectives of grounded theory, hermeneutics, critical theory and postmodernism. Grounded theory, the first level of interpretation recommended by the authors, utilizes an analysis of empirical data as a basis for developing a theory or as a stimulus for further investigations. The hermeneutic approach focuses on interpretation and emphasizes that all research is an act of interpretation, as is human perception itself. Critical theory and postmodern perspectives take the interpretation of research into the level of meta-theory by problematizing the "legitimacy of dominant interpretive patterns" $(2009,276)$. 
The positioning of the researcher in the multi-paradigmatic relationship to the empirical data begs the question of in/commensurability of paradigms. Guba and Lincoln pronounce a "cautious yes" to the commensurability of constructivism and interpretivist/postmodern critical theory, whilst also emphasizing the contradictory and mutually exclusive axioms of positivist and interpretivist approaches $(2005,201)$. Although Alvesson and Sköldberg (2009) do not appear to explicitly express any paradigmatic preferences, their simultaneous movement 'within' and 'between' diverse theoretical perspectives has two implications. Firstly, it implies a degree of commensurability between the levels of interpretation recommended by the authors. In warning against researchers getting "stuck in a particular paradigm... captivated by their own language games," the authors thus advocate methodological pluralism (2009, 308). Secondly, such pluralism implies that social reality is constructed in diverse ways depending on the epistemological positioning of social actors. Social constructionism, postmodernism and critical theory challenge taken-for-granted ways of understanding the world and seek alternatives to realism and post/positivism (Burr 2003). They acknowledge that all ways of understanding are rooted in history, culture and social institutions. Consequently, the notion of "truth" is problematic, as is the idea of language being a neutral medium for representing reality. Burr's argument that "no human can step outside their humanity" to become an objective, expert knower of "truth" $(2003,152)$ is crucial for understanding reflexivity. Bound up by our humanity, we are inextricably involved in social life, immersed in the complex networks of agents, institutions and events.

Paradoxically, however, reflexivity requires both an acknowledgement of this involvement and, simultaneously, a degree of detachment, particularly in 
relation to oneself. With its roots in Hegelian dialectical logic, which acknowledges "contradiction as 'necessity"' (Marcuse 2002, 146), the notion of paradox illuminates two contradictory processes inherent in reflexivity, involvement and detachment. Although the self is always involved, immersed in its own humanity, crucial to developing individual self-awareness is also detachment, 'stepping outside' to examine oneself (Elias 1987). As Elias (1987) points out, the evolution of human consciousness has been predicated on developing higher levels of detachment, leading to an increasing awareness of the 'I' involved in the social world. However, some interpretations of reflection and reflexivity appear to perpetuate what Elias refers to as the "I without we" (1987, lxi), the sense of self existing in isolation or separation from others. The following study of postgraduate curriculum design suggests that models of reflective practice may accentuate the "I without we".

\section{Case study of curriculum design}

The aim of the MA Education curriculum project was to deepen students' understanding of reflection with a view to improving their professional practice. The student group comprised qualified teachers working in schools across London. In order to enhance student learning, I was guided by the principle of 'constructive alignment' of module outcomes, syllabus, learning activities, assessment criteria and assessment tasks (Biggs 1996). Seeing constructive alignment as recommended good practice in Higher Education (Cowan, George, and Pinheiro-Torres 2004), I planned a number of activities and tasks focusing on reflection. They included: an evaluation and application of reflective learning models (Kolb 1984; Pedler, Burgoyne, and Boydell 2003; Schön, 1983, 1987), critical incident technique (Moon 2004) and discussion of Dewey's (1910) 
explication of reflective thought. An assessment task of writing a reflective portfolio seemed to be well aligned to these activities and to the core module outcome, i.e. the ability of students to demonstrate a 'critical' engagement in reflection. Reflection, crucial in teacher training (TDA 2007), has been a focus of University-wide policies post-Dearing (1997). At Masters level, engagement in reflection would need to address the Quality Assurance Agency (QAA 2008) criteria for Level 7. Of relevance to Masters students would be critical awareness, self-direction and recognition of complexity, which would enable them to make decisions in "complex and unpredictable situations" (QAA 2008, 20-21).

The research was a case study (Stake 1995) of an MA module which examined whether constructive alignment (Biggs 1996) enhanced students' learning of 'critical' reflection. Case study data comprised: students' module evaluations, assessment results and students' reflective portfolios. The findings presented in this paper are supported by extracts from students' portfolios selected to illustrate the often ambiguous or problematic nature of the empirical material. The module evaluations and assessment results suggested that students' learning of reflection had been enhanced. However, problematising the case study data at four levels of interpretation recommended by Alvesson and Sköldberg (2009) begs further questions. The first one concerns the value of reflection as a curriculum outcome. The notions of teaching and learning reflection and constructive alignment also merit further consideration. Lastly, my own positioning as a teacher-researcher needs to be reflexively evaluated. These questions are explored at four levels of interpretation to which this paper will now turn.

\section{The level of grounded theory: an analysis of empirical material}


For Alvesson and Sköldberg (2009) grounded theory is an important empiricallyoriented research approach. The focus of grounded theory on the minutiae of micro-worlds of everyday practice enhances its practical utility and enables the development of complex, subtle, finely nuanced understandings. It also raises the status of an 'ordinary' social researcher who, by theorizing practice, confirms that anyone can create theory, not just the "great men" such as "Marx, Weber, Durkheim, Mead, etc." (Glaser and Strauss 1967 as quoted in Alvesson and Sköldberg 2009, 57). However, the authors argue that data oriented methods risk creating "trivial knowledge" if the researcher disregards the ambiguities of language and the influence of the political-ideological context of scientific enquiry.

I recognize the above risk as a problem with my initial case study design, which narrowly focused on learning conceptualized as a logical, step-by-step process of application of 'new' knowledge. Through a systematic engagement with the case study data, I sought to understand how students progress in their learning of reflection and how I could further support their learning. An analysis of students' reflective portfolios resulted in the following 'progress chart' (Figure 1):

Figure 1 inserted here (above)

The chart became my 'diagnostic tool' for identifying the 'next steps' in students' learning in the context of formative and summative feedback and evaluation. In hindsight, the chart's simplicity and utility value anchored my teaching practice in a reductive framework of logical incrementalism. Within this framework, the reflective portfolios appeared to demonstrate, as 'evidence' of learning, both students' own reflection and references to theoretical frameworks for reflection 
discussed in module sessions. The following extract by 'Anna' (a pseudonym), a secondary Mathematics teacher, pointing to the benefits of reflection, merits attention as 'evidence of learning':

I realize that reflection prevents me from cultivating an over-positive and dogmatic habit of mind (Pollard 2002). "To be genuinely thoughtful, we must be willing to sustain and protract that state of doubt which is the stimulus to thorough inquiry" (Pollard 2002, 4). Reflective teachers can benefit from professional development only when their minds are open to change. (from Anna's portfolio)

However, as Alvesson and Sköldberg (2009) point out, qualitative empirical data are ambiguous. The above extract can be interpreted in a number of ways: as a record of making sense of experience, as 'evidence of learning' which contributes to a grade, or a measure of a relative 'success' of my curriculum design. These readings could also be challenged: is Anna's writing an expression of a genuine voice or an attempt to meet assignment marking criteria? What are the consequences of assigning a percentage grade to a tutor's pre-conceived notion of students' understanding of reflection? In assuming the role of a more knowledgeable other (Vygotsky 1978), does the tutor enhance student learning, or does she endorse the "axiom of inequality" which underpins education and other social systems (Rancière 2010, 6)?

Anna's extract suggests that her reflective portfolio task enhanced attitudes which, according to Dewey (1916), can be cultivated through reflection. However, a comparison of the extract with the published source raises questions regarding the authenticity of Anna's writing:

One can think reflectively only when one is willing to endure suspense and to undergo the trouble of searching. To many persons both suspense and 
judgement and intellectual search are disagreeable; they want to get them ended as soon as possible. They cultivate an over-positive and dogmatic habit of mind, or feel perhaps that a condition of doubt will be regarded as evidence of mental inferiority... To be genuinely thoughtful, we must be willing to sustain and protract that state of doubt which is the stimulus to thorough inquiry. (Dewey 1910 as quoted in Pollard 2002, 4)

Is Anna's reflection a genuine expression of profound changes in thinking, or simply a paraphrase of the original text intended to impress the examiner and thus an example of "pseudo-reflection" (Moore 2004, 109)? And, even if the latter is the case, to what extent does it matter? If we agree with the premise that "a meaning of a word is its use" (Wittgenstein 1953, 43), then by using language we create meanings "while language works on us" (Bleakley 2000, 19). Therefore, the act of writing down a paraphrase of the original text may have led Anna to a genuine understanding.

Another issue which merits attention at the level of empirical data is to what extent my position as a teacher-researcher affected the case study findings. In order to examine the relationship between the constructive alignment of module curriculum and students' learning of 'critical' reflection, I developed research instruments which focused in particular on the perceived cause (constructive alignment) and effect (enhanced learning of reflection). However, both the notion of constructive alignment and the single cause - single effect research can be contested. The former has been criticized for creating rigid, teacher-centered curricular 'packages' which exclude creativity, impede emergent learning and stifle the development of student agency (Hussey and Smith 2003; Knight 2001). The predictability of learning outcomes contradicts the QAA (2008) expectation that holders of a Masters qualification are able to make decisions in complex, unpredictable situations. The single cause - single effect 
thinking reduces the plethora of factors which can enhance learning to one variable. Thinking back about my engagement in the project, I recognize that in those early days of teaching in higher education, I saw my students' 'success' as 'evidence' of my teaching competence. From the grounded theory perspective, further research could have addressed the issue of trustworthiness of the case study, however, a hermeneutic interpretation of the curriculum design project leads to a different set of questions, which are discussed below.

\section{The level of hermeneutics: trapped in the hall of mirrors}

At the level of hermeneutics, "the meaning of symbols becomes central" (Alvesson and Sköldberg 2009, 318). Rooted in phenomenology, hermeneutics seeks to understand our everyday experience, a process which does not depend solely on reason, but is predicated on intuition, empathy and insight. Key to hermeneutical understanding is the acknowledgement that "we always belong to the world" and our perception and interpretations are historically conditioned (Alvesson and Sköldberg 2009, 121). Consequently, this perspective rejects the notion of an objective, expert researcher-scientist, disconnected from the objects of his investigations. In seeking meaning, hermeneutic researchers explore the historical roots of our current understandings of the world, paying particular attention to the metaphorical and narrative aspects of language. Narrative sensemaking relies on putting experience into words, in the presence of the other. Hermeneutic understanding emerges from conversations with others, unlike the knowledge generated by the solitary subject implicit in the metaphor of reflection.

As one of the most powerful metaphors in the Western society (Edwards and Nicoll 2006), reflection has many interpretations. It implies a realist view of the world which privileges a visual appreciation of reality. It is a manifestation of 
"a cultural obsession with the mirror" and narcissistic tendencies (Bleakley 1999, 320). Mirrors can also distort reality and result in "warped and twisted forms of reflection" (Foucault 1970, 343), as reflection turns to self-surveillance.

Consequently, the mirror metaphor signifies both reality and illusion, freedom to realize the self and self-imposed imprisonment. The discourse of reflection may be interpreted as a language game which positions reflection as intrinsically worthwhile and thus essential for leading a worthwhile life (Bleakley 1999; Edwards and Nicoll 2006). Our socialization into the language game of the reflective human being entices us to accept such understanding of reflection as the norm; by conforming to the norm we re-construct and perpetuate this way of making sense of the world.

The enduring effect of the reflection metaphor could therefore be interpreted as legitimizing certain ontological and epistemological approaches. Ontologically, the mirror metaphor constructs dualistic distinctions between the observer and external reality, between the realms of objects and ideas, between seeing and other senses. An epistemological critique of the metaphor of the mind as a great mirror reflecting nature is presented by Rorty, who posits that, since the Enlightenment, knowledge has been conceptualized as "accurate representation" $(1979,12)$. In challenging the "ocular metaphors" which dominate Western thinking, Rorty points out that they are simply a historical phenomenon, a social construct:

The picture which holds traditional philosophy captive is that of the mind as a great mirror, containing various representations... Without the notion of the mind as mirror, the notion of knowledge as accuracy of representation would not have suggested itself. Without this latter notion, the strategy common to Descartes and Kant - getting more accurate representations by inspecting, repairing, and polishing the mirror, so to speak - would not have made sense. (Rorty 1979, 12) 
Implicit in the 'grand' metaphor of reflective practice is a passive self reflecting an objective reality. However, as Giddens argues, "the self is not a passive entity, determined by external influences; in forging their self-identities... individuals contribute to and directly promote social influences" $(1991,2)$. The view of human agency as both constituted and constitutive is developed further by Elias (1991), who posits that the humankind, rather than the single individual, needs to be a frame of reference for epistemological considerations. This is because humans are not independent, but interdependent, oriented towards and linked with each other in diverse ways (Elias 1978). Interdependence contradicts the notion of a priori knowledge, the I-centered mental activity which asserts the autonomous, knowing subject objectifying what is to be known:

The traditional human image associated with thought, and thus also with mind, is that of an isolated human individual... I am no longer following that tradition. Communication in the form of human speech... presupposes as the normal form of living a life in groups. So does the activity we call thinking. (Elias 1991, 81)

Knowledge can be acquired in two interconnected ways: through personal experience (a posteriori) and via communication with others. The symbols of language learned by individuals introduce them to what Elias refers to as the "social fund of knowledge" (1991, 113). 'Samantha', a work-placement coordinator in her secondary school, seems to be on the threshold of such understanding in her critique of the 'misuse' of reflective practice:

I believe that there is a tendency to misuse reflective practice and find that there is a need for... bringing reflexive practice to the fore, allowing for the development of socially aware teachers who listen to voices other than their own. (from Samantha's writing) 
Samantha appears to be on the threshold of a new horizon of understanding, premised on the view of the individual as interdependent, unlike the "I without we" promoted by mainstream interpretations of reflective practice. The notion of interdependence of human agents entails that reflection on an action has meaning only when it accounts for what it means both for the reflecting individual and for others: "the meaning of an action for the actor is codetermined by the meaning it may have for others" (Elias 1991, 49). Within a wider epistemological frame, it also points to the importance of the dynamic, dialectic processes of knowledge construction, in which articulation in the social context is central. Creating new understandings...

cannot be performed single-handedly by one individual. It is a task which can only be performed by the co-operation of many individuals through a sequence of generations. (Elias 1991, 143)

The questions which arise at this level of interpretation concern my role as a teacher of reflection. What were the consequences of setting the students the reflective portfolio task? Have I been instrumental in trapping the students in the hall of mirrors - in 'coercing' them into a socially accepted meaning of reflection and thus in promoting a certain ontological and epistemological positioning? Or have I facilitated understanding, which, according to Elias (1991), Rorty (1979) and phenomenological writers, is a matter of engagement in dialogue?

Hermeneutic understanding is predicated on the "fusion of horizons" (Gadamer 2004). The concept of horizon situates understanding within our individual, historically limited field of meaning. "Fusion of horizons" denotes continuous mediation of meaning and new understandings which emerge as a result of conversations with others. The movement back and forth between ours and others' horizons "leads to the gradual revising and/or enriching of our own" 
(Alvesson and Sköldberg 2009, 120). At this level of interpretation, we are reminded that, "to be human is to be concerned with meaning, to desire meaning" and this "desire to make sense... is not just a psychological state; it is a state of being" (Van Manen 1990, 79). At this level, therefore, the pedagogical situation researched through my case study presents itself as a narrative account of lived experience of the students and the teacher-researcher engaged in making sense of the complex lifeworld in which reflection is one of the central themes.

\section{'Smoke and mirrors': a critical theory perspective}

Critical theory's focus on the political dimensions in research highlights social actors' responsibility for emancipatory social change. Alvesson and Sköldberg (2009) refer to this perspective as a meta-theory, because it seeks a critical interpretation of the dominant forms of understanding. The authors argue that its emancipatory impulse arises from explorations of the deep structures of unquestioned values and beliefs which, at the level of surface structures, "give rise to frozen social institutions and locked thought and action" $(2009,168)$. Driven by the principle of thinking in a dialectic way, critical theory negates the existing social order, allowing for alternatives to be imagined. At this level of interpretation, the focus is on the ways in which dominant ideologies may be uncritically taken for granted and reproduced both through teaching and research practices.

A critical theory view exposes the hidden curriculum, driven by the dominant political ideology and surfacing as the 'newspeak' of standardization and outcomes (Kelly 2004). The ideal of reflective practice popularized by Schön (1987), has been subsequently trivialized by such documents as the Dearing Report 1997 or the Personal, Learning and Thinking Skills (PLTS) curriculum for 
secondary pupils (QCA 2007). These policies standardize reflection as a crucial skill for the members of the "learning society" (Dearing 1997), "needed for success in learning and life" (QCA 2007). Both documents present reflection as unproblematic and shallow, as a means to an end. For example, Chapter 8 of the Dearing Report, Students and Learning, which is 5,000 words in length, has only two references to reflection. In one of its 88 Recommendations, the Report briefly refers to reflection in the context of Personal Development Planning (PDP). PDP is described as:

a structured and supported process undertaken by an individual to reflect upon their own learning and/or achievement and to plan for their personal education and career development. (Recommendation 20, Dearing 1997)

Reflection is presented here as a straightforward activity of evaluating prior learning or achievement with a view to future development. Whilst Dearing (1997) promotes reflection without engaging in its definitions or in relation to broader aims of education, the PLTS curriculum (QCA 2007) explicitly frames the outcomes of reflective learning as a range of "skills, behaviours and personal qualities." Reflective learners are described as...

Young people [who] evaluate their strengths and limitations, setting themselves realistic goals with criteria for success. They monitor their own performance and progress, inviting feedback from others and making changes to further their learning. (QCA 2007)

The themes of success, performance and progress which frame this description resonate with Dearing's (1997) model of reflective learning. Reflective learners are future oriented, 'busy' young people. Engaging in reflection is a simple, agreeable process, as Dewey's (1910) doubt and "trouble of searching" are being replaced with dealing "positively with praise, setbacks and criticism" (QCA 
2007). The actions of assessing, goal setting and monitoring performance take reflective learners step-by-step through the learning cycle, steering them away from unrealistic goals, which might make them 'unsuccessful'. What is ignored in this model is reflection as a meaning-making process. Reflection has been reduced to a skill which can be performed and linked to observable outcomes, such as 'success'. The discourse of reflection becomes a disciplinary mechanism (Foucault 1977), producing an educated person who, in accordance with the current political doctrine, is employable, successful, ready for life and work in the "learning society". However, a subject prepared for living in a capitalist, neoliberal society is "malleable rather than committed, flexible rather than principled - essentially depthless" (Ball 2012, 31). He is in possession of 'expert' skills. In the modern capitalist society, which has evolved from democracy to "expertocracy," experts hold the power over what is legitimate and possible (Bauman 2005). In Bauman's analysis, experts build their authority on the basis of "assured" meanings, as they are "almost by definition people who "get the facts straight", who take the facts as they come and think of the least risky way of living in their company" (2005, 1094-95). Expert solutions, however, come at a cost to democratic relations, by creating the divide between experts and non-experts. In a truly democratic society, argues Bauman, all individuals have freedom to create meanings for their lives and are able to participate in deciding whether they want "a life under the conditions that are being presented to [them]" $(2005,1094)$.

As a secondary teacher, Samantha is accountable for teaching the PLTS curriculum to her pupils and, simultaneously, obliged to participate in the disciplinary rituals of 'forced reflection'. She argues that...

What should be explored is the value of the reflection undertaken as an integral part of a teaching career. There is a dichotomy between truly reflective processes 
and those which masquerade as true reflection, but are in effect bureaucratic recording processes. Recorded reflection satisfies school recording processes and feeds into the school improvement machine; supposedly evidencing improvement in practice on an individual level. Lesson plan templates often include a small box for forced reflection... (from Samantha's writing)

Negating the processes which 'masquerade as true reflection' creates opportunities for imagining alternatives, such as 'educative' or 'critical' reflection. For Samantha, an alternative is afforded by reflexivity. For Dewey the "educative value" of reflection is rooted in deliberate attempts to unearth taken for granted assumptions, when...

...the ground or basis for a belief is deliberately sought and its adequacy to support the belief is examined. This process is called reflective thought; it alone is truly educative in value. (Dewey 1910,2)

For Barnett, the emancipatory purpose of higher education is underpinned by critical reflection which needs to "take on knowledge itself" in order to create "imaginary alternatives" and lead to constructive action (1997, 5-7). In the light of these arguments, the focus of teaching reflection shifts from promoting the dominant normative values to encouraging agency and responsibility to act, rather than being acted upon. As Harré and Gillett emphasize, such action starts with an examination of one's meaning and value systems:

It is my evaluations of my own activity that are the ultimate effective source of semantic conformity. As semantics (or meanings) are the core of intentionality... I am therefore a participant in and not merely an object of social causation. (Harré and Gillett 1994, 118)

Harré and Gillett argue that "freedom is a discursive activity," something that we do, rather than have $(1994,113)$. At the level of critical theory, teaching 
(and researching) with integrity is a political action, which aims at raising the consciousness of social actors, seeks to open spaces for "doing freedom" and allows discussions of possible ideological bias (Grace 1998). By becoming reflexive, reflective portfolios could engage students in questioning their own assumptions and opinions, interrogating the origins of their beliefs and scrutinizing their ontological and epistemological foundations.

\section{Shattered mirror and postmodern kaleidoscopic patterns of reflection}

By breaking away from the modern tendency to build knowledge on the firm foundations of 'grand narratives', postmodernism simultaneously shatters the conception of the mind as the mirror of nature (Rorty 1979). As Alvesson and Sköldberg explain, postmodernism dispels the myth of universal laws, "rational, global solutions and explanations" and replaces it with "microhistories - local, always provisory and limited stories" $(2009,180)$. Postmodern life fragments our day-to-day existence and our being. It also shatters the idea of researcher identity as singular, stable and fixed (Thomson and Gunter 2011). Each fragment of experience is then reflected in the multiple mirrors of diverse theoretical and ideological perspectives. Constantly shifting kaleidoscopic patterns, made up of tensions, ironies and paradoxes, emerge as a result. As Alvesson and Sköldberg point out, an interpretation of research at this level will be permeated with irony. Perhaps the most relevant irony would be Schön's (1987) notion of reflection itself. His concept of the reflective practitioner was an alternative to models of professionalism based on technical rationality:

Technical rationality is an epistemology of practice derived from positivist philosophy built into the very foundations of the modern research university... 
Technical rationality holds that practitioners are instrumental problem solvers who select technical means best suited to particular purposes. (Schön 1987, 3)

Used in the "indeterminate zones of practice - uncertainty, uniqueness, and value conflict" (Schön 1987: 6), reflection complements other non-technical rational professional qualities: "outstanding practitioners are not said to have more professional knowledge than others but more 'wisdom,' 'talent,' 'intuition,' or 'artistry"' (13). However, as Bleakley (1999) points out, Schön's failure to develop his model of reflective practice as artistry and his examples which present reflection as a technique, may lead to interpretations of Schön's reflection from a technical-rational perspective. This can be illustrated by the following account of a critical incident narrated by 'Mark', a secondary Geography teacher:

On reflection, I had made the right choice when I decided to stop the argument with the Inspector and report it to my Head of Department. This decision is supported by Schön's (1983) model of 'framing' and 're-framing' the situation. When the argument started, I framed the situation by identifying the problem, its parameters and factors relevant in the situation. As the problem persisted and the Inspector would not accept my explanation, I decided to change the 'parameters' and 're-frame' the problem - I went to seek advice from my Head of Department. (from Mark's reflective portfolio)

Mark's analysis of a critical incident is underpinned by Schön's (1983) steps in the process of reframing. This extract can be read as an example of a student drawing on a theoretical framework to explain practice, a welcome Masters level outcome (QAA 2008). However, it also reads like a technical 'matching exercise', in which the unfolding critical incident is fitted into the stages of framing and reframing. Lost in this technical-rational process are not only the underlying emotions, but also reflection as "the trouble of searching" (Dewey 1910, 22), rather than an affirmation of the 'right choice'. Mark's reframing could, 
therefore, be interpreted as engagement in reflection which is essentially unreflective, promoting "reaffirmation of belief rather than a tool for exploration and for thinking otherwise" (Ball 1995 as quoted in Ecclestone 1996, 152). A more detailed narrative account of the communication between Mark and the Inspector could have allowed him to explore the Inspector's perspective. Ironically, however, academic writing conventions recommend developing critical analysis and keeping narrative description to a minimum (Moon 2004; Wallace and Wray 2006). In the light of the postmodern claim that "all writing is narrative writing," an alternative approach, respecting Mark's and other students' voices, would acknowledge them as "situated speakers, subjectivities engaged in knowing/telling the world as they perceive it" (Richardson and St. Pierre 2005, 961).

Models of reflective practice can thus be interpreted as locking practitioners into one particular type of subjectivity, which privileges rationality over other psychic functions, such as intuition or recognition of the unconscious. As Jung (1964) points out, excessive rationalism stunts the development of the Western psyche. An alternative mirror metaphor, which would allow for a more balanced development, is that of a "tarnished mirror" (Hawthorne 1992, 52-54), seen in moonlight, "one remove further from the actual." Looking in the "tarnished mirror" liberates the observer from the 'objective' reality seen in broad daylight and takes her to the world of imagination and the unconscious. In Jungian (1964) terms, facing the "darkness inside" enables an integration of the shadow, which is a prerequisite for self-transcendence. With his tarnished mirror metaphor, Hawthorne, a 19th century fiction writer, embraces a 20th century insight that: 
We can no longer deny that the dark stirrings of the unconscious are active powers, that psychic forces exist which, for the present at least, cannot be fitted into our rational world order. (Jung 1971, 463)

From the psychoanalytic perspective, Britzman (1998) argues for an education which would recognize the unconscious, "haunted," "bothered" aspects of self. This is because, having replaced doubt and ambivalence with a relentless focus on standardization, performativity and culture of success, the technicalrational education can be destructive for the self:

devastating experiences within the self occur when education bonds with idealization, denies its own difficulties and the difficulties of others, and involves the absolute splitting of good and bad and of failure and success in terms that disregard human complexity. (Britzman 2003, 7)

As Elliott and Lemert (2006) point out, being "wrecked by success" is a commonplace paradox of our times.

In place of reflection, Britzman advocates reflexivity, whereby the teacher seeks an understanding of his own development "as it plays through, repeats, and becomes elaborated within the teacher's relations with individual children, school knowledge, other adults, and, of course, the teacher's own self" $(1998,9)$. Such reflexivity is also essential for the postmodern researcher, who acknowledges that, ironically, educational research is "unavoidably, a rhetorical affair, or 'fabrication'" (MacLure 2003, 80). Just like reflection, however, reflexivity may also be reduced to "techniques for telling the reflexive self" (Skeggs 2002). Skeggs criticizes approaches in which reflexivity is constructed as a...

normative requirement of rigorous methodology, when really it is merely a mechanism by which the romantic aesthetics of the whole and coherent self are put into place in the name of intellectual practice. (Skeggs 2002, 352) 
Techniques for telling the reflexive self often build the authority of the researcher by de-authorizing the articulations of research participants. Reporting the movement of the researcher's reflexive self can simultaneously fix others. Skeggs concludes that there is a difference between claims to reflexivity as a technique for authorizing oneself and doing reflexivity in practice. Assuming a position of a detached spectator, a position of power over research participants, may easily lead to objectifying others as "resources for self-formation" (369). Reflexivity as practice, however, is about researchers repeatedly asking: "Can we hear?" Reflexivity in action is about...

...a movement from telling and confession to practice and positioning. This is a call for accountability and responsibility in research, not for self-formation and self-promotion. (Skeggs 2002, 369)

The tension in accounts of reflexivity as practice is, however, inevitable, because of the detachment inherent in the process of accounting. The very process of telling is a movement away from being involved, immersed in practice to narrating action. It is a process of detaching (Elias 1987). As I narrate my experience of being reflexive in action, in my research practice, I use the signs of language and, to make my personal meanings available to the reader, I refer to reflexivity objectified as definitions, conceptualizations, accounts and insights by other researchers. Such "intellectualization of method" (Alvesson and Sköldberg $2009,1)$ draws me further into abstraction, away from being immersed in reflexivity as practice.

Paradoxically, however, such detachment from the self is also crucial for being reflexive. I recall moments of being there for my students-research 
participants, being attentive to, and respectful of the learning journeys narrated in class and their reflective portfolios and simultaneously being aware of who I am in terms of my "position," "investment," "habitus," "history," and "politics" (Skeggs 2002, 368). In these moments I experienced being reflexive; a teacherresearcher in an interdependent relationship with students, where the 'I' cannot exist without the 'we' and power is mutual.

\section{Conclusion: constructing possible alternative futures}

This paper has sought to highlight the importance of reflexivity in teaching and qualitative research. Engaging with empirical material at four levels of interpretation illuminates the problematic nature of both. Whilst the above discussions problematize the post/modern practices of reflection and reflexivity and trace their historical roots, my concluding thoughts turn to possible futures by asking: 'What would happen, if...?' To overcome the tendency to look back, inherent in reflexivity, a reflexive researcher-teacher needs to also engage in considerations which attempt "to bridge where we are and where we might end up" (Cherryholmes 1999, 3). Where we might end up, if unreflective/unreflexive modes of teaching and learning continue to be practiced, is a "learning society" whose citizens have been educated to submission rather than freedom. Biggs's $(1996,2003)$ framework for constructive alignment may be a helpful technique for designing the curriculum, as a technical starting point rather than a prescription for the complete process. The metaphors chosen by Biggs imply the latter:

The key is that the components in the teaching system, especially the teaching methods used and the assessment tasks, are aligned with the learning activities assumed in the intended outcomes. The learner is in a sense 'trapped', and finds it difficult to escape without learning what he or she is intended to learn. (Biggs 2003) 
The use of passive voice in relation to the learner, who "is intended to learn" a set of outcomes, introduces external, enforced intentionality which denies students their agency. Outcomes-based education is equivalent to conceiving the "development of mind as an outcome", argues Barnett; it is a "hopelessly limited way of construing higher education" $(1994,81)$. Interpreting Biggs's framework from multiple theoretical perspectives begs further questions about the "intended outcomes": Whose intentionality do they promote? Whose interests are these intentions meant to serve? On whose authority? And what would happen if the 'reflective student' discarded the step-by-step recipes for success endorsed by the learning society? What if the 'reflective practitioner' resisted the prevailing political perspectives and reductionist approaches to knowledge they promote? What would emerge from a recognition that the nature of knowledge, language and thought presupposes social, rather than individual processes of learning, working and living (Elias 1991)?

As Harré and Gillett (1994) point out, constructing possible alternative futures starts as a discursive action. This argument calls for a recognition that what is communicated to students in the process of education may construct particular versions of the world for them to know and accept. Consequently, the main task of education would be to create opportunities for students to explore diverse perspectives, discourses and universes of meaning:

One needs to live, to visit, to know intimately more than one such universe to spy out human invention behind any universe's imposing and apparently indomitable structure... (Bauman 2005, 1092)

The "indomitable structure" of privileged, expert meanings becoming the dominant reality needs to be critically examined and contested, if the current 
advance of "expertocracy" is to be arrested. Alvesson and Sköldberg's (2009)

invitation to visit the universes of grounded theory, hermeneutics, critical theory

and postmodernism can be, therefore, viewed as open to all: the educator,

researcher and student. It is an invitation to engage in a reflexive practice which

seeks to "intimately know" these universes, to become involved but not "trapped"

in their systems of meaning, always remaining free to detach.

\section{References}

Alvesson, Matts, and Kaj Sköldberg. 2009. Reflexive Methodology: New Vistas for Qualitative Research. 2nd ed. London: Sage Publications.

Ball, Stephen J. 1995. "Intellectuals of Technicians? The Urgent Role of Theory in Educational Studies." British Journal of Educational Studies 43 (3): 255-271. doi: 10.1080/00071005.1995.9974036.

Ball, Stephen J. 2012. Global Education Inc.: New policy networks and the neo-liberal imaginary. London and New York: Routledge.

Barnett, Ronald. 1997. Higher Education: A Critical Business. Buckingham: SRHE and Open University Press.

Barnett, Ronald. 1994. The Limits of Competence: Knowledge, Higher Education and Society. Buckingham: SRHE and Open University Press.

Bauman, Zygmunt. 2005. "Afterthought: On Writing; On Writing Sociology." Chap. 43 in The Sage Handbook of Qualitative Research, edited by Norman K. Denzin and Yvonna S. Lincoln. 3rd ed., 191-215. Thousand Oaks: Sage Publications.

Biggs, John. 1996. "Enhancing teaching through constructive alignment." Higher Education 32 (3): 347-364. doi: 10.1007/BF00138871.

Biggs, John. 2003. Aligning teaching for constructing learning. Accessed 2 September 2012.

http://www.heacademy.ac.uk/resources/detail/resource_database/id477_aligning_teaching _for_constructing_learning.

Bleakley, Alan. 1999. "From Reflective Practice to Holistic Reflexivity." Studies in Higher Education 24 (3): 315-330. doi: 10.1080/03075079912331379925.

Bleakley, Alan. 2000. "Writing With Invisible Ink: narrative, confessionalism and reflective practice." Reflective Practice 1 (1): 11-24. doi: 10.1080/713693130.

Boler, Megan. 2008. "The politics of making claims: challenges of qualitative, web-based research." Chap. 1 in The Methodological Dilemma: Creative, collaborative approaches to qualitative research, edited by Kathleen Gallagher, 11-33. Oxon: Routledge. 
Britzman, Deborah P. 1998. Lost Subjects, Contested Objects: Toward a Psychoanalytic Inquiry of Learning. New York: Suny.

Britzman, Deborah P. 2003. After-Education: Anna Freud, Melanie Klein, and Psychoanalytic Histories of Learning. Albany: State University of New York Press.

Burr, Vivien. 2003. Social Constructionism, 2nd ed. Hove: Routledge.

Cherryholmes, Cleo H. 1999. Reading Pragmatism. New York: Teachers College Press.

Cowan, John, Judith W. George, and Andreia Pinheiro-Torres. 2004. "Alignment of developments in higher education." Higher Education 48 (4): 439-459. doi:

10.1023/B:HIGH.0000046722.64326.dc.

Dearing, Ron. 1997. Higher Education and the Learning Society. London: Stationery Office.

Dewey, John. 1910. HOW WE THINK. Boston: D C Heath and Company.

Dewey, John. 1916. Democracy and Education. Accessed 5 August 2012. http://www.ilt.columbia.edu/publications/dewey.html.

Ecclestone, Kathryn. 1996. "The reflective practitioner: mantra or a model for emancipation?" Studies in the Education of Adults 28 (2): 148-160.

Edwards, Richard, and Katherine Nicoll. 2006. "Expertise, competence and reflection in the rhetoric of professional development." British Educational Research Journal 32 (1): 115-131. doi: 10.1080/01411920500402052.

Elias, Norbert. 1978. What is Sociology? Great Britain: Hutchinson \& Co (Publishers) Ltd.

Elias, Norbert. 1987. Involvement and Detachment. London: Blackwell.

Elias, Norbert. 1991. The Symbol Theory. London: Sage Publications Ltd.

Elliott, Anthony, and Charles Lemert. 2006. The new individualism: the emotional costs of globalization. London: Routledge.

Foucault, Michel. 1970. The Order of Things: an archaeology of the human sciences.London: Tavistock.

Foucault, Michel. 1977. Discipline and Punish: the birth of the prison. London: Allen Lane.

Gadamer, Hans-Georg. 2004. Truth and Method. 2nd ed. London: Continuum.

Giddens, Anthony. 1991. Modernity and Self-Identity: Self and Society in the Late Modern Age. Cambridge: Polity Press.

Glaser, Barney G., and Anselm L Strauss. 1967. The Discovery of Grounded Theory: Strategies for Qualitative Research. Chicago: Aldine.

Grace, Gerald. 1998. "Critical Policy Scholarship: Reflections on the Integrity of Knowledge and Research." Chap. 13 in Being Reflexive in Critical Educational and 
Social Research, edited by Geoffrey Shacklock and John Smyth, 202-217. London:

RoutledgeFalmer.

Guba, Egon G., and Yvonna S. Lincoln. 2005. "Paradigmatic Controversies, Contradictions and Emerging Confluences." Chap. 8 in The Sage Handbook of Qualitative Research, edited by Norman K. Denzin and Yvonna S. Lincoln. 3rd ed., 191215. Thousand Oaks: Sage Publications.

Harré, Rom, and Grant Gillett. 1994. The Discursive Mind. Thousand Oaks: Sage.

Hawthorne, Nathaniel. 1992. The Scarlet Letter. Ware: Wordsworth Editions Limited.

Hussey, Trevor, and Patrick Smith. 2003. "The Uses of Learning Outcomes." Teaching in Higher Education 8 (3): 357-368. doi: 10.1080/13562510309399.

Jung, Carl G., ed. 1964. Man and his Symbols. London: Aldus Books Limited.

Jung, Carl G. 1971. "The Spiritual Problem of Modern Man." Chap. 12 in The Portable Jung, edited by Joseph Campbell. Harmondsworth: Penguin Books.

Kelly, Albert V. 2004. The Curriculum: theory and practice. London: Sage Publications.

Knight, Peter T. 2001. "Complexity and Curriculum: a process approach to curriculummaking." Teaching in Higher Education 6 (3): 369-381.

doi: 10.1080/13562510120061223.

Kolb, David A. 1984. Experiential Learning: experience as the source of learning and development. New Jersey: Prentice-Hall.

Marcuse, Herbert. 2002. One-Dimensional Man: Studies in the ideology of advanced industrial society. London and New York: Routledge Classics.

MacLure, Maggie. 2003. Discourse in Educational and Social Research. Maidenhead: Open University Press.

Moon, Jennifer A. 2004. A Handbook of Reflective and Experiential Learning: Theory and Practice. London: RoutledgeFalmer.

Moore, Alex. 2004. The good teacher: Dominant discourses in teaching and teacher education. London: Routledge.

Pedler, Mark, John Burgoyne, and Tom Boydell. 2003. A Manager's Guide to Leadership. Maidenhead: McGraw-Hill.

Pollard, Andrew, ed. 2002. Readings for Reflective Teaching. London: Continuum.

Quality Assurance Agency (QAA) 2008. The framework for higher education qualifications in England, Wales and Northern Ireland. Accessed 3 August 2010. http://www.qaa.ac.uk/Publications/InformationAndGuidance/Pages/The-framework-forhigher-education-qualifications-in-England-Wales-and-Northern-Ireland.aspx.

Qualifications and Curriculum Agency (QCA) 2007. Personal, learning and thinking skills. Accessed 27 June 2013.

http://webarchive.nationalarchives.gov.uk/20091212080722/http://curriculum.qcda.gov.u k/key-stages-3-and-4/skills/plts/index.aspx. 
Rancière, Jacques. 2010. "On Ignorant Schoolmasters." Chap. 1 in Jacques Rancière: Education, Truth, Emancipation: Charles Bingham and Gert J.J. Biesta, with Jacques Rancière, edited by Charles Bingham and Gert Biesta, 1-24. London: Continuum.

Richardson, Laurel, and Elizabeth Adams St. Pierre. 2005. "Writing: A Method of Inquiry." Chap. 38 in The Sage Handbook of Qualitative Research, edited by Norman K. Denzin and Yvonna S. Lincoln. 3rd ed., 959-978. Thousand Oaks: Sage Publications.

Rorty, Richard. 1979. Philosophy and the Mirror of Nature. Princeton and Oxford: Princeton University Press.

Schön, Donald A. 1983. The Reflective Practitioner: how professionals think in action. New York: Basic Books.

Schön, Donald A. 1987. Educating the Reflective Practitioner. San Francisco: JosseyBass.

Skeggs, Beverley. 2002. "Techniques for Telling the Reflexive Self." Chap. 17 in Qualitative Research in Action, edited by Tim May, 349-375. London: Sage Publications Ltd.

Stake, Robert E. 1995. The Art of Case Study Research. Thousand Oaks: Sage Publications, Inc.

Training and Development Agency (TDA) 2007. Professional Standards for Teachers in England from September 2007. Accessed 27 June 2013. http://webarchive.nationalarchives.gov.uk/20110316231736/http://tda.gov.uk/teacher/dev eloping-career/professional-standards-guidance/downloads.aspx.

Thomson, Pat, and Helen Gunter. 2011. "Inside, outside, upside down: the fluidity of academic researcher 'identity' in working with/in school." International Journal of Research \& Method in Education 34 (1): 17-30. doi: 10.1080/1743727X.2011.552309.

Van Manen, Max. 1990. Researching Lived Experience: human science for an action sensitive pedagogy. New York: Suny.

Vygotsky, L.S. 1978. Mind in Society: The Development of Higher Psychological Processes. Cambridge, Massachusetts: Harvard University Press.

Wallace, Mike, and Alison Wray. 2006. Critical Reading and Writing for Postgraduates. London: Sage Publications.

Wittgenstein, Ludwig. 1953. Philosophical Investigations. Translated by G.E. Anscombe. Oxford: Basil Blackwell. 